\title{
Teaching NeuroImages: Cytotoxic lesions of the corpus callosum in encephalopathic patients with COVID-19
}

Myriam Edjlali, MD, PhD, Aurélie Le Gal, MD, Martin Louvet, MD, Morgan Matt, MD, Christophe Leveque, MD, Caroline Diffre, MD, David Orlikowski, MD, PhD, Djillali Annane, MD, PhD, and Robert-Yves Carlier, MD, PhD, on behalf of The Garches COVID-19 Collaborative Group

Neurology ${ }^{\circledR}$ 2020;95:1021-1022. doi:10.1212/WNL.0000000000010880

Figure Typical aspect of cytotoxic lesion of the corpus callosum (CLOCC) in patients positive for COVID-19
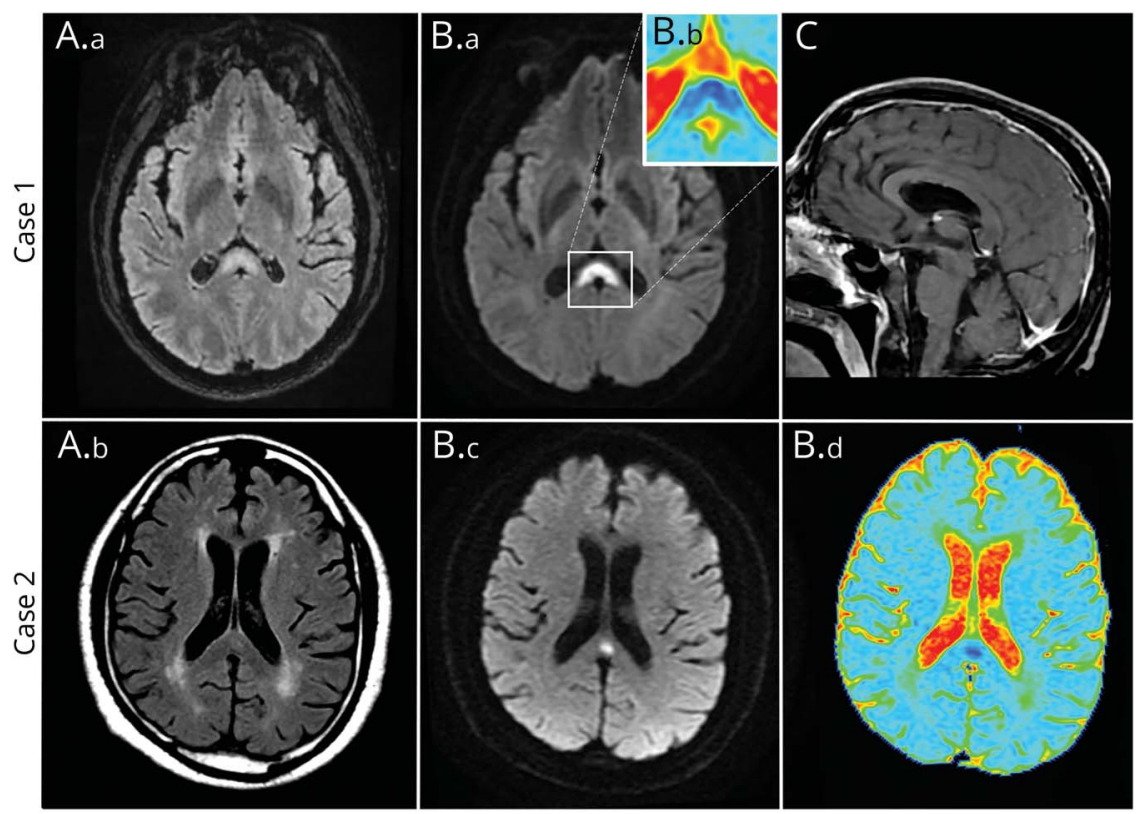

Ovoid lesion of the splenium of the corpus callosum, with increased T2/FLAIR signal (A.a, A.b), diffusion-weighted imaging hyperintensity (B.a, B.C) with abnormal restricted diffusion on multichromatic apparent diffusion coefficient maps (B.b, B.d) (ADC values $\left.<500 \times 10^{-6} \mathrm{~mm}^{2} / \mathrm{s}\right)$, and reduced T1 signal without enhancement (C).

\section{Correspondence}

Dr. Edjlali

myriam.edjlali@gmail.com

\section{MORE ONLINE}

$\rightarrow$ Teaching slides

links.lww.com/WNL/

B239

\section{COVID-19 Resources}

For the latest articles, invited commentaries, and blogs from physicians around the world

NPub.org/COVID19
Two men, aged 49 and 51 years, with acute encephalopathy and rapid clinical deterioration were transferred to the intensive care unit. Both were recently tested positive for coronavirus disease 2019 on nasopharyngeal swab. On brain MRI, a lesion of the splenium of the corpus callosum was found, with T2-FLAIR hyperintensity and restricted diffusion (figure). This pattern is characteristic of cytotoxic lesion of the corpus callosum, an entity described previously as secondary to an underlying cause such as infection, drug toxicity, subarachnoid hemorrhage, history of CNS malignancy, or metabolic disorders. ${ }^{1}$ These lesions are nonischemic lesions, usually transient and reversible on

From the Department of Radiology (M.E., C.D., R.-Y.C.), APHP, Hôpitaux R. Poincaré-A Paré, DMU Smart Imaging, GH Université Paris-Saclay; Department of Neuroradiology (M.E.), Université Paris-Descartes-Sorbonne-Paris-Cité, IMABRAIN-INSERM-UMR1266, DHU-Neurovasc, Centre Hospitalier Sainte-Anne, Paris; Department of Internal Medecine (A.L.G., M.M.), APHP, Hôpitaux R. Poincaré-A Paré, DMU Smart Imaging, GH Université Paris-Saclay; Department of Imaging (M.L., C.L.), Hôpital Privé de Parly II, Le Chesnay; and FHU SEPSIS (Saclay and Paris Seine Nord Endeavour to PerSonalize Interventions for Sepsis) (D.O., D.A.), RHU RECORDS (Rapid rEcognition of CORticosteroiD resistant or sensitive Sepsis), Department of Intensive Care, Hôpital Raymond Poincaré (GHU APHP Université Paris Saclay), Laboratory of Infection \& Inflammation-U1173, School of Medicine Simone Veil, University Versailles Saint Quentin-University Paris Saclay, INSERM, Garches, France.

Go to Neurology.org/N for full disclosures. Funding information and disclosures deemed relevant by the authors, if any, are provided at the end of the article.

The Garches COVID-19 Collaborative Group coinvestigators are listed at links.Iww.com/WNL/B238 
follow-up. The underlying mechanism relies on the vulnerability of the splenium of the corpus callosum to cytokinopathy.

\section{Study funding}

No targeted funding reported.

\section{Disclosure}

The authors report no disclosures. Go to Neurology.org/N for full disclosures.

\begin{tabular}{lll} 
Appendix 1 & Authors & \\
\hline Name & Location & Contribution \\
\hline $\begin{array}{l}\text { Myriam } \\
\text { Pdjlali, MD, }\end{array}$ & $\begin{array}{l}\text { APHP, DMU Smart } \\
\text { Imaging, GH Université } \\
\text { Paris-Saclay, France }\end{array}$ & $\begin{array}{l}\text { Designed and conceptualized } \\
\text { the study; analyzed the data; } \\
\text { and drafted the manuscript } \\
\text { for intellectual content }\end{array}$ \\
\hline $\begin{array}{l}\text { Aurélie Le } \\
\text { Gal, MD }\end{array}$ & $\begin{array}{l}\text { APHP, GH Université } \\
\text { Paris-Saclay, France }\end{array}$ & $\begin{array}{l}\text { Major role in the acquisition } \\
\text { of data }\end{array}$ \\
\hline $\begin{array}{l}\text { Martin } \\
\text { Louvet, MD }\end{array}$ & Hôpital Privé de Parly II, & $\begin{array}{l}\text { Major role in the acquisition } \\
\text { of data }\end{array}$ \\
$\begin{array}{l}\text { Morgan } \\
\text { Matt, MD }\end{array}$ & $\begin{array}{l}\text { APHP, GH Université } \\
\text { Paris-Saclay, France }\end{array}$ & $\begin{array}{l}\text { Revised the manuscript for } \\
\text { intellectual content }\end{array}$ \\
\hline $\begin{array}{l}\text { Christophe } \\
\text { Leveque, } \\
\text { MD }\end{array}$ & $\begin{array}{l}\text { Hôpital Privé de Parly II, } \\
\text { Le Chesnay, France }\end{array}$ & $\begin{array}{l}\text { Revised the manuscript for } \\
\text { intellectual content }\end{array}$ \\
\hline
\end{tabular}

Appendix 1 (continued)

\begin{tabular}{lll}
\hline Name & Location & Contribution \\
\hline $\begin{array}{l}\text { Caroline } \\
\text { Diffre, MD }\end{array}$ & $\begin{array}{l}\text { APHP, GH Université } \\
\text { Paris-Saclay, France }\end{array}$ & $\begin{array}{l}\text { Major role in the acquisition } \\
\text { of data }\end{array}$ \\
\hline $\begin{array}{l}\text { David } \\
\text { Orlikowski, } \\
\text { MD, PhD }\end{array}$ & $\begin{array}{l}\text { APHP, GH Université } \\
\text { Paris-Saclay, France }\end{array}$ & $\begin{array}{l}\text { Analyzed the data and revised } \\
\text { the manuscript for } \\
\text { intellectual } \\
\text { content }\end{array}$ \\
\hline $\begin{array}{l}\text { Djillali } \\
\begin{array}{l}\text { Annane, } \\
\text { MD, PhD }\end{array}\end{array}$ & $\begin{array}{l}\text { APHP, GH Universite } \\
\text { Paris-Saclay, France }\end{array}$ & $\begin{array}{l}\text { Analyzed the data and revised } \\
\text { the manuscript for } \\
\text { intellectual content }\end{array}$ \\
$\begin{array}{l}\text { Robert- } \\
\text { Yves } \\
\text { Carlier, MD, } \\
\text { PhD }\end{array}$ & $\begin{array}{l}\text { APHP, DMU Smart } \\
\text { Imaging, GH Université }\end{array}$ & $\begin{array}{l}\text { Analyzed the data and revised } \\
\text { the manuscript for } \\
\text { intellectual content }\end{array}$ \\
\hline
\end{tabular}

Appendix 2 Coinvestigators

Coinvestigators are listed at links.Iww.com/WNL/B238

\section{Reference}

1. Starkey J, Kobayashi N, Numaguchi Y, Moritani T. Cytotoxic lesions of the corpus callosum that show restricted diffusion: mechanisms, causes, and manifestations. Radiogr Rev Publ Radiol Soc N Am Inc 2017;37:562-576.

\section{NEW EPISODE}

\section{ค}

$\underset{\text { PODCAST }}{\text { Neurology }}$

December 1, 2020

\section{Idiopathic distal sensory polyneuropathy: ACTTION diagnostic criteria (see p. 1005)}

In the first segment, Dr. Stacey Clardy talks with Dr. Roy Freeman about his paper discussing idiopathic distal sensory polyneuropathy. In the second part of the podcast, Dr. Clardy speaks with Dr. Justin McArthur about his research, work, and the National Academy of Medicine Award.

Disclosures can be found at Neurology.org.

CME Opportunity: Listen to this week's Neurology Podcast and earn 0.5 AMA PRA Category 1 CME Credits ${ }^{\mathrm{TM}}$ by completing the online Podcast quiz. 


\section{Neurology}

\section{Teaching NeuroImages: Cytotoxic lesions of the corpus callosum in encephalopathic patients with COVID-19}

Myriam Edjlali, Aurélie Le Gal, Martin Louvet, et al.

Neurology 2020;95;1021-1022 Published Online before print September 16, 2020

DOI 10.1212/WNL.0000000000010880

This information is current as of September 16, 2020

\begin{tabular}{|c|c|}
\hline $\begin{array}{l}\text { Updated Information \& } \\
\text { Services }\end{array}$ & $\begin{array}{l}\text { including high resolution figures, can be found at: } \\
\text { http://n.neurology.org/content/95/22/1021. full }\end{array}$ \\
\hline References & $\begin{array}{l}\text { This article cites } 1 \text { articles, } 0 \text { of which you can access for free at: } \\
\text { http://n.neurology.org/content/95/22/1021.full\#ref-list-1 }\end{array}$ \\
\hline Citations & $\begin{array}{l}\text { This article has been cited by } 1 \text { HighWire-hosted articles: } \\
\text { http://n.neurology.org/content/95/22/1021.full\#\#therarticles }\end{array}$ \\
\hline Subspecialty Collections & $\begin{array}{l}\text { This article, along with others on similar topics, appears in the } \\
\text { following collection(s): } \\
\text { Encephalitis } \\
\text { http://n.neurology.org/cgi/collection/encephalitis }\end{array}$ \\
\hline Permissions \& Licensing & $\begin{array}{l}\text { Information about reproducing this article in parts (figures,tables) or in } \\
\text { its entirety can be found online at: } \\
\text { http://www.neurology.org/about/about_the_journal\#permissions }\end{array}$ \\
\hline Reprints & $\begin{array}{l}\text { Information about ordering reprints can be found online: } \\
\text { http://n.neurology.org/subscribers/advertise }\end{array}$ \\
\hline
\end{tabular}

Neurology ${ }^{\circledR}$ is the official journal of the American Academy of Neurology. Published continuously since 1951, it is now a weekly with 48 issues per year. Copyright (C 2020 American Academy of Neurology. All rights reserved. Print ISSN: 0028-3878. Online ISSN: 1526-632X.

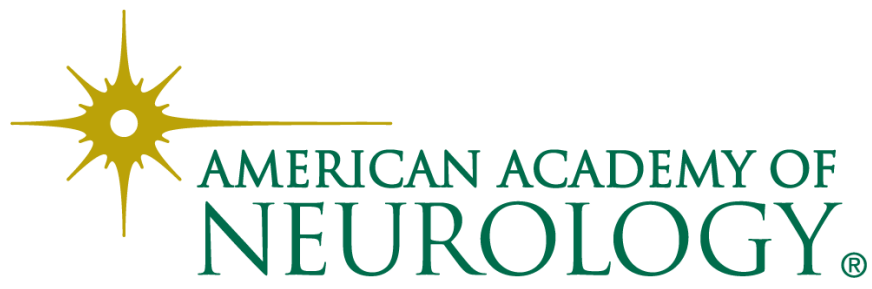

